\section{EMBRYRIDDLE \\ Aeronautical University}

SCHOLARLY COMMONS

\section{International Journal of Aviation,} Aeronautics, and Aerospace

\title{
ICAO Aviation System Block Upgrades: A Method for Identifying Training Needs
}

Becky Lutte

University of Nebraska at Omaha Aviation Institute, rlutte@unomaha.edu

Follow this and additional works at: https://commons.erau.edu/ijaaa

Part of the Business Administration, Management, and Operations Commons, International Business Commons, Technology and Innovation Commons, and the Training and Development Commons

\section{Scholarly Commons Citation}

Lutte, B. (2015). ICAO Aviation System Block Upgrades: A Method for Identifying Training Needs. International Journal of Aviation, Aeronautics, and Aerospace, 2(4). https://doi.org/10.15394/ ijaaa.2015.1090

This Article is brought to you for free and open access by the Journals at Scholarly Commons. It has been accepted for inclusion in International Journal of Aviation, Aeronautics, and Aerospace by an authorized administrator of Scholarly Commons. For more information, please contact commons@erau.edu. 
Since the mid-1970s, air traffic growth has expanded two-fold once every fifteen years (ICAO, 2013). The ICAO Global Air Navigation Plan (GANP) is a roadmap to achieve a "vision of an integrated, harmonized, and globally interoperable air traffic management (ATM) system" (ICAO, 2012, p. 1). A component of the GANP is the Aviation System Block Upgrades (ASBU), a framework for achieving that vision. A collaborative approach led by ICAO between public and private organizations and member states resulted in the development of the ASBU framework. However, obstacles exist for successful implementation. One area of concern is the need for training of qualified personnel including air navigation service providers, flight crews, and those responsible for safety oversight. While the ICAO strategy has the potential to enhance global interoperability through such means as information sharing and management, more efficient flight paths, and improvements to airport operations, obstacles must first be overcome. The purpose of this research is to develop a template that can be used to identify the training needs associated with the implementation of the ASBU modules. The template can be applied by selected groups within individual ICAO member states to determine a customizable training plan allowing the state to maximize benefits from implementing ASBU modules.

\section{Creation of the ASBU}

In 2010, the $37^{\text {th }}$ session of the ICAO General Assembly resulted in a directive to address the growing needs of global interoperability while maintaining an emphasis on safety as air traffic levels rise (ICAO, 2011). The future of air navigation requires a significant investment. An estimated $\$ 120$ billion will be spent in the next ten years on system upgrades worldwide (Benjamin, 2011). The need for a flexible plan for air navigation modernization to guide these changes was recognized. A customizable framework for implementation of system upgrades was necessary due to the varying operations, infrastructure, and resources of member states around the world. It was important to focus on a flexible and scalable plan based on the needs and level of readiness of member states. The goals for a global ICAO air navigation plan included meeting the needs for:

- a uniform level of safety across all regions

- optimized traffic flow across all regions

- common system-to-system connectedness and data sharing

- common performance requirements, standards, and operating procedures

- environmental objectives

- common security standards (CANSO, 2013)

The process of developing a plan to meet these goals included "an intense round of collaboration" (ICAO, 2013, p. 10). ICAO conducted a series of outreach 
events in every world region (ICAO, 2013). Input from key stakeholders was provided at the 2011 Global Air Navigation Industry Symposium (Benjamin, 2011). Feedback received led to the development of the Aviation System Block Upgrade framework. The framework was further refined at the $12^{\text {th }}$ Air Navigation Conference held at ICAO headquarters in 2012 (ICAO, 2012b). At the conference, Carlos Cirilo of the International Air Transport Association (IATA), an organization that represents $85 \%$ of the world's airlines, expressed support for the ASBU initiative and stated his concern that "traffic growth is outpacing technology" (Cirilo, 2012). The final draft of the ASBU strategy was endorsed by the ICAO Assembly in 2013 and was included in the $4{ }^{\text {th }}$ Global Air Navigation Plan (GANP), ICAO Document 9750 (ICAO, 2013).

The ASBU framework was developed using a collaborative approach with cooperation from states, international organizations, and industry (Benjamin, 2011). This represents a new way of doing business and a new way of thinking by ICAO according to Vince Galotti (2012), Deputy Director, Safety Standardization and Infrastructure, Air Navigation Bureau, ICAO. Development of the ASBU framework has been described as an "unprecedented global effort" (Korsakov, 2012). The initiative was designed through a collaborative approach to meet the needs for current and future air navigation, resulting in the development of a customizable plan to meet the needs of each member state.

\section{Components of the ASBU}

The ASBU framework provides a roadmap for ICAO member states for air navigation modernization. The ASBUs consist of "clearly defined, measurable operational improvements", known as modules (CANSO, 2013, p. 6). The modules are grouped together in blocks. Blocks are implemented according to a timetable with a block of modules targeted for implementation every five years (Figure 1). For example, Block 0 consists of a set of modules available for implementation in 2013. Block 1 consists of modules that will be available for implementation in 2018. Subsequent blocks are planned for every five years. An example module from Block 0 is B0-WAKE, increased runway throughput through optimized wake turbulence separation (ICAO, 2013b). This module will increase arrival and departure capacity through revision of ICAO wake separation minima (ICAO, $2013 \mathrm{~b}$ ). The modules are categorized into one of four improvement areas. The four improvement areas are airport operations, globally interoperable systems and data, optimum capacity and flexible flights, and efficient flight paths (ICAO, 2013). The ICAO working document (2013b) presents each module along with key implementation information such as required technologies, procedures, performance measures, and training requirements. 


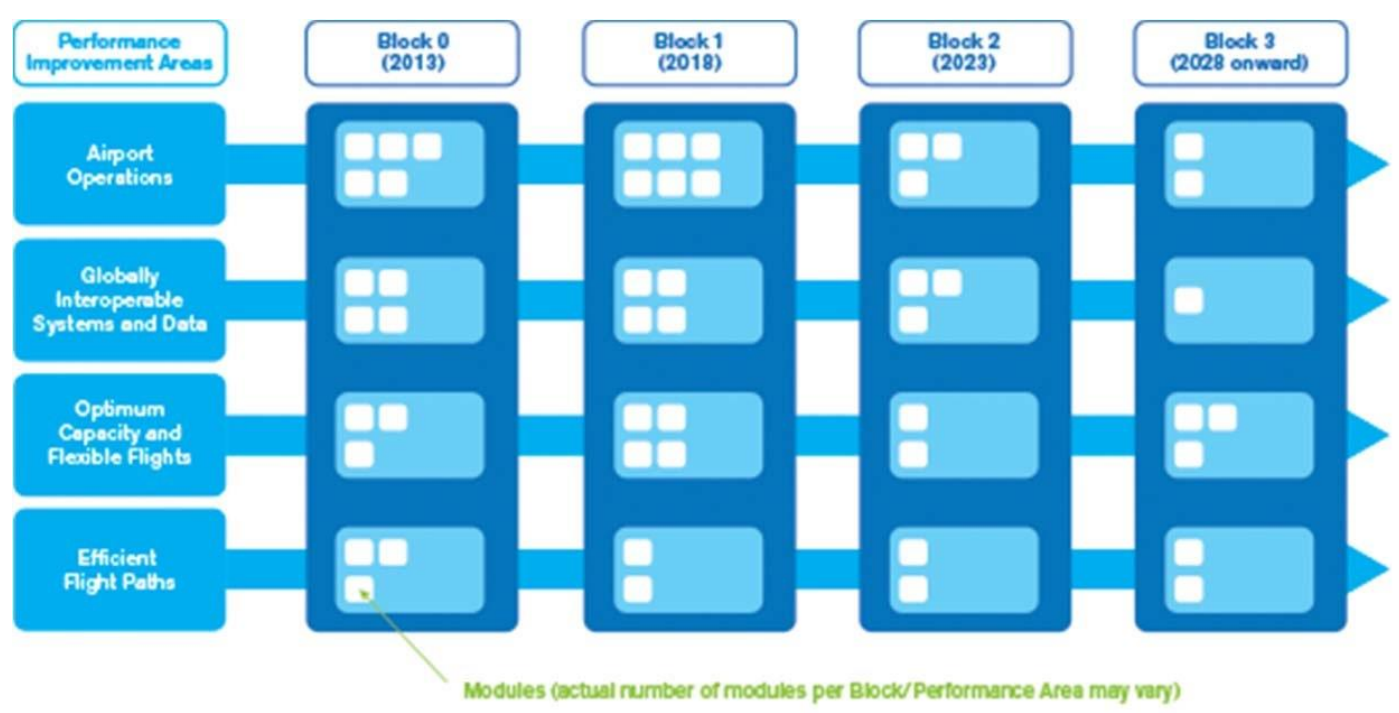

Figure 1. The ASBU model (ICAO, 2013)

Modules in block 0 have been finalized and are ready for implementation now with the related ICAO Standards and Recommended Practices (SARPS) in place. Block 1 is still in the consensus building stage to finalize the modules and necessary SARPS and is slated to be ready in 2018 .

A key characteristic of the ASBU strategy is flexibility (Abeyratne, 2014). Different member states will evaluate the modules and implement selected modules according to their specific operational requirements. Not all modules will be necessary in all parts of the world. Implementation is based on factors including need, resources, and level of readiness.

Although the plan is designed to be flexible and scalable, successful deployment of block 0 modules, specifically the modules related to performance based navigation $(\mathrm{PBN})$, are the cornerstone for global interoperability. If the priority modules for block 0 are not implemented as a foundation, certain functionalities may not be available as enablers for future blocks (Moussa, 2012). The three priorities for block 0 are performance based navigation (PBN), continuous descent operations (CDO), and continuous climb operations (CCO) (Moussa, 2012). In the most recent GANP and Air Navigation Report, ICAO listed PBN as the highest priority goal for global air navigation (ICAO, 2013; ICAO, 2014). ICAO is providing training aids for the implementation of PBN such as the 
PBN ikit (ICAO, 2013c). ICAO tracks the levels of global implementation of PBN on a publicly available web site (ICAO, 2014b).

\section{Obstacles to Implementation}

There are challenges to implementing the ASBU strategy. States may not be capable of ensuring successful deployment of block 0 (Moussa, 2012). Implementation challenges identified by ICAO include implementation of ground systems and essential avionics, procedures availability, and operational approvals (ICAO, 2013d). Concerns over the regional impact of implementation decisions by individual member states exist. A significant obstacle is the need for training. According to IATA's Cirilo, a "main roadblock is lack of expertise. We need to invest in training. If not, we won't be successful" (Cirilo, 2012). The delegate from Niger agreed, "training is important. Need to focus on putting importance on training" (Moussa, 2012). It is generally agreed that "there is a great desire but lack of knowledge" to proceed (Galotti, 2012). Eugene Hoeven, director of ICAO Affairs, from Civil Air Navigation Services Organization (CANSO) encouraged the participants at the $12^{\text {th }}$ Air Navigation Conference workshop to look at training early. CANSO has 170 members globally who handle $85 \%$ of the world's air traffic. Hoeven (2012) also raised concerns regarding oversight stating "regulators have lost expertise to evaluate providers". This raises a serious obstacle for successful implementation of the ASBU. The importance of properly trained aviation professionals and adequate oversight by civil aviation authorities could make or break this global effort. ICAO recognizes the importance of determining training needs associated with the ASBU strategy (M. Hoummady, personal communication, November 16, 2012).

\section{Purpose}

The purpose of this research is to address a key question related to the implementation of the ASBU modules. How can the training needs associated with the implementation of the ASBU modules be identified? Conducting a training needs assessment is an essential step in order to develop training solutions to meet the needs of the member state. Developing solutions without properly identifying needs runs the risk of "overdoing training, doing too little training, or missing the point completely" (Brown 2002, p. 559). Training initiatives that introduce the concept of the ASBU framework and focus on managing the implementation of modules are currently offered by IATA (IATA, 2014) and CANSO (CANSO, 2014). However, there is a need for focusing on additional training specifically related to procedures and integration of technology. As noted in the recently 
published ICAO Air Navigation Report (ICAO, 2014), over the next triennium, ICAO will focus on training related goals including:

- the need for guidance material, workshops, and symposia

- computer based learning packages

- formal training courses to ensure that PBN requirements and standards are fully understood and properly implemented

- support in order to ensure harmonized and integrated implementation of related technologies and support tools to optimize performance capability objectives (ICAO, 2014, p. 20)

For the purpose of this project, training will refer to training in operational standards and procedures related to the ICAO ASBU modules. Are system users keeping pace with the new technology? Do key stakeholders have the necessary training to meet the performance capabilities of the ASBU modules? The targeted audience to explore training needs will include three key stakeholder groups, the air navigation service providers (ANSPs), flight crews, and aviation regulatory oversight personnel. As noted in the GANP (ICAO 2013):

The system changes will affect the work of many skilled personnel in the air and on the ground, potentially changing their roles and interactions and even requiring new proficiencies to be developed. It is critical therefore that the concepts being developed within the GANP take account of the strengths and weaknesses of existing skilled personnel at every juncture. All actors with a stake in a safe air transportation system will need to intensify efforts to manage risks associated with human performance and the sector will need to proactively anticipate interface and workstation design, training needs and operational procedures (p. 20).

\section{Methodology}

A literature review was conducted to develop a gap analysis template to identify training needs related to the implementation of the ASBU modules. Multiple sources were used to develop the template. They included document review, interviews with key personnel, and participation at the $12^{\text {th }}$ Air Navigation ASBU workshop.

Gap analysis is a broad range of techniques used to examine and describe differences between current conditions and desired conditions (Stolzer, Halford, \& Goglia, 2010). For the purpose of this study, the focus will be on developing a knowledge gap analysis. Exploring the knowledge gap can provide recognition that current knowledge is not sufficient to achieve expected performance (Petersen, 
Pedersen, \& Lyles, 2008). Knowledge gaps tend to occur when there is a change in environment, technological changes or policy or regulatory changes (Transport Canada, 2012, Peterson, et.al., 2008). The ability to identify and resolve these knowledge gaps prior to implementation can greatly impact the implementation process (Lin \& Shu-Mei Tseng, 2005).

The gap analysis is the appropriate design for this template for several reasons. First, it allows one to address the question posed by identifying gaps in training in each module. In addition, gap analysis is widely used in aviation, particularly throughout ICAO member states, and is therefore a familiar tool. It has been used to identify strengths and weaknesses to enhance aviation safety (ICAO, n.d.; Leib \& Lu, 2013; TRB, 2009; CAA, 2010; IATA 2015). The FAA recommends the use of gap analysis to identify missing components of existing processes and procedures needed to meet proposed requirements (FAA, 2013). The gap is widely used in the area of implementation of safety management systems (FAA, 2012; IATA, 2008). Benefits of conducting a gap analysis to identify training needs include the ability to identify specific problem areas, use of the analysis to obtain management support, and the ability to target resources where needed most (Brown, 2002).

Development of the gap analysis specifically for the purpose of identifying training needs associated with the implementation of the ASBU modules began with the collection of information. The initial source was a series of conversations between the researcher and key personnel at ICAO. Additional review of ASBU documents and information and input received at the $12^{\text {th }}$ Air Navigation ASBU Workshop also contributed. Three options for developing the gap analysis template were explored; utilize an existing gap analysis design, modify a gap analysis design, or create a new design. Upon review of several gap analysis designs by ICAO, FAA, Transport Canada, airports, and aviation consultants, a previously prepared gap analysis template was selected and modified. The format of the gap analysis template was based on a previous gap analysis design developed by ICAO (ICAO, 2013e.) and adopted by other organizations such as Transport Canada (Transport Canada, 2014) and AviAssist (AviAssist, 2014). This design was selected because it is widely used in international aviation and the user-friendly, simplified format provides a workable design to be applied by any member state.

The design was modified to present each module in block 0 . Block 0 modules were selected because they are currently available to all member states for implementation and are considered a key element of the overall ASBU strategy. ICAO documentation provides details for each block. The working document for the aviation system block upgrades (ICAO, 2013b) provides detailed information 
for each module within a block. It includes a summary, applicability consideration, how it relates to the global plan, prerequisites, and provides targeted performance measures. In addition, the National ASBU Implementation Plan - Guidance on Elements, Equipage, and Measurement was a source for identifying additional module requirements (ICAO, 2015). Utilizing this information, a gap analysis template was developed to identify the module, the need for training, and action required.

The training questions listed were developed based upon document reviews and interviews with ICAO personnel. The primary document used was the Working Document for the Aviation System Block Upgrades (ICAO, 2013b). Specific references to the training requirements in the modules are provided in the gap analysis template for further clarification as needed. The gap analysis template is presented in Appendix A. Due to the size of the full template, an abbreviated version is presented in the appendix. The full version can be viewed and downloaded at http://dx.doi.org/10.13140/RG.2.1.1526.3442 (Lutte, 2015).

\section{Outcomes}

The outcome of the research is development of a tool to identify training needs associated with the implementation of the ASBU modules. Like the ASBU framework, the gap analysis template is designed to be flexible based on the needs of the member state. The template can be used to address training needs for safety oversight personnel, air navigation service providers, airline training departments, or a combination of targeted groups. The process of conducting the training needs gap analysis allows for identification of weaknesses in regards to implementation of procedures and management of automation. The analysis can assist in the identification of potential new roles and responsibilities for personnel, risks associated with human performance, and whether strategies to mitigate those risks have been identified. Use of the analysis allows target groups to consider each of these areas for each individual module of Block 0.

A potential challenge to completing the training gap analysis is identification of selected modules implemented by the state. Since each member state has the flexibility to implement selected modules, it will be important to initially identify which modules the state has implemented or plans to implement. This information can be obtained through sources such as the ICAO Air Navigation Report (ICAO, 2014). The Air Navigation Report provides information on the progress of implementation of the ASBU modules throughout ICAO regions, based on information provided by member states on the Air Navigation Report Form (ICAO, 2013d). Additionally, some member states (Brazil, Canada, China, India) 
are mapping their current air navigation system to the block upgrades to identify areas of compatibility (ICAO, 2013).

For further research, the next step is to apply the gap analysis template to identify training needs for a targeted group or groups within a member state. As noted, the target group can include the ANSPs, aircraft operators, or safety oversight personnel from the CAA or a combination of the three. The gap analysis tool can then be implemented by providing the instrument to the intended target group for completion through such means as targeted interviews, focus groups, or surveys (Brown, 2002). Use of interviews, surveys, or target group completion, or a combination of the three methods should be determined based on accessibility, resources, and size of target group. Additional clarification of results can be accomplished through follow-up interviews and further document review. Analysis of the results will reveal the need for specific training solutions.

\section{Conclusion}

Identifying training needs associated with implementing ASBU modules will provide important information for successful implementation of the ASBU strategy. This research has resulted in a tool to be applied to identify needs specific to a member state. By recognizing the areas for further training, steps can be taken to develop appropriate training solutions to fill identified gaps. Such plans may include training workshops or courses. Implementing a global framework for the modernization of air navigation is a critical task. Identifying the training needs associated with implementation of the ASBU strategy is a key element to achieve the maximum benefits of this global initiative. The ASBU framework represents a new approach to the modernization of air navigation worldwide. To enhance safety, address sustainability, and become a globally interoperable system, new operational improvements will result in new roles and responsibilities placed on aviation professionals. To meet the demands of the future, training needs must be identified today. 


\section{References}

Abeyratne, R. (2014). The aviation system block upgrades: Legal and regulatory issues. Air \& Space Law, 39(2), 131-154.

AviAssist. (2014). Guidance on the development of an SMS Gap Analysis for service providers. Retrieved from http://www.aviassist.org/imageslogo//ICAO\%20SMS\%20Gap\%20Analysis.p df.

Benjamin, R. (2011, September). Address by the Secretary General of the ICAO. Speech presented at the Global Air Navigation Industry Symposium, ICAO headquarters, Montreal.

Brown, J. (2002). Training needs assessment: A must for developing an effective training program. Public Personnel Management, 31(4), 569-574. Retrieved from http://dx.doi.org/10.1177/009102600203100412.

CAA. (2010). Safety management systems: Guidance to organisations. Retrieved from http://www.caa.co.uk/docs/872/30JulySMS\%20Guidance\%20Materialversion 3.pdf.

CANSO. (2013). Introduction to the aviation system block upgrade (ASBU) modules: Strategic planning for ASBU modules implementation. Montreal: MITRE.

CANSO. (2014). Methodology and best practices for ASBU implementation. Retrieved from https://www.canso.org/asbu-implementation-training.

Cirilo, Carlos (2012, November). IATA Viewpoint. Speech presented at $12^{\text {th }}$ Air Navigation Conference, ICAO headquarters, Montreal.

FAA (2012). SMS implementation guide. Washington DC: FAA.

FAA (2013). SMS Gap analysis conference. Retrieved from http://www.faa.gov/news/conferences_events/sms_gap/.

Galotti, V. (2012, November). Opening Remarks. Speech presented at $12^{\text {th }}$ Air Navigation Conference, ICAO headquarters, Montreal. 
Hoeven, E. (2012, November). CANSO Viewpoint. Speech presented at $12^{\text {th }}$ Air Navigation Conference, ICAO headquarters, Montreal.

IATA. (2008). Gap analysis: DTW SMS. Montreal: IATA.

IATA. (2014). Managing the implementation of Aviation System Block Upgrades $A S B U s$. Retrieved from http://www.iata.org/training/courses/Pages/absuimplementation-tvvg02.aspx.

IATA. (2015). IATF: The bridge over training gaps. Retrieved from http://www.iata.org/publications/training-news/Pages/archive-2015q2-newitdi.aspx.

ICAO. (n.d.). Africa ICAO gap analysis: ICAO AFI Plan. Retrieved from http://www.icao.int/safety/afiplan/Pages/default.aspx.

ICAO. (2011). ICAO and industry join forces to shape the future air navigation system (Press release). Retrieved from http://www.icao.int/Newsroom/Pages/icao-and-industry-join-forces-to-shapethe-future-air-navigation-system.aspx.

ICAO. (2012). Twelfth air navigation conference: Communications roadmap. (ICAO Doc AN-Conf/12-IP/2). Montreal: ICAO.

ICAO (2012b). Twelfth air navigation conference: Draft report of the committee on agenda item 1. (ICAO Doc AN-Conf/12-WP/156). Montreal: ICAO.

ICAO. (2013). Global air navigation plan. (ICAO Doc 9750-AN-963). Montreal: ICAO.

ICAO. (2013b). Working document for the aviation system block upgrades: The framework for global harmonization. Montreal: ICAO.

ICAO (2013c). PBN ikit. Retrieved from http://www.icao.int/safety/pbn/PBNiKitV3/story.html.

ICAO (2013d). Sample template: Air navigation report form. Retrieved from http://www.icao.int/sustainability/Pages/ASBU-Framework.aspx.

ICAO. (2013e). Safety management manual. (ICAO Doc 9859-AN-474). Montreal: ICAO. 
ICAO. (2014). ICAO air navigation report 2014 edition. Montreal: ICAO.

ICAO. (2014b). ICAO PBN. Retrieved from http://gis.icao.int/icaostatus/map.html?webmap=dd34dc34e66d4d298fdf9494 $99 \mathrm{c} 47 \mathrm{c} 30$.

ICAO. (2015). National ASBU implementation plan - Guidance on elements, equipage, and measurement. Retrieved from http://www.icao.int/sustainability/Pages/ASBU-Framework.aspx.

Korsakov, Alexander. (2012, November). ASBUs Next Steps. Speech presented at $12^{\text {th }}$ Air Navigation Conference, ICAO headquarters, Montreal.

Leib, S. \& Lu, C. (2013). A gap analysis of airport safety using ICAO SMS perspectives: A field study of Taiwan. Journal of Aviation Technology and Engineering, 2(2). 63-70.

Lin, C., \& Shu-Mei Tseng. (2005). The implementation gaps for the knowledge management system. Industrial Management + Data Systems, 105(1), 208222. Retrieved from http://dx.doi.org/10.7771/2159-6670.1078.

Lutte, R. (2015). ASBU training gap analysis. Retrieved from http://dx.doi.org/10.13140/RG.2.1.1526.3442.

Moussa, H. (2012, November). ASBU Block 0 Overview. Speech presented at $12^{\text {th }}$ Air Navigation Conference, ICAO headquarters, Montreal.

Petersen, B., Pedersen, T., \& Lyles, M. A. (2008). Closing knowledge gaps in foreign markets. Journal of International Business Studies, 39(7), 1097-1113. Retrieved from http://dx.doi.org/10.1057/palgrave.jibs.8400409.

Stolzer, A., Halford, C., Goglia, J. (2010). Safety management systems in aviation. Burlington, VT: Ashgate.

TRB. (2009). Safety management systems for airports: Volume 2: Guidebook (ACRP Report 1). Washington, DC: Transportation Research Board.

Transport Canada. (2012). Civil aviation process for identification in learning (SI- ADM-033). Transport Canada. 
International Journal of Aviation, Aeronautics, and Aerospace, Vol. 2 [2015], Iss. 4, Art. 5

Transport Canada. (2014). Gap analysis form. Retrieved from http://www.tc.gc.ca/eng/civilaviation/publications/tp14343-appendixb610.html. 


\section{Appendix A}

\section{ASBU Training Needs Gap Analysis}

Note: Due to the size of the full gap analysis template, only two modules are presented here. The full template is available at http://dx.doi.org/10.13140/RG.2.1.1526.3442.

Each question is designed for a "yes" or "no" response. A "no" indicates a gap exists. Please indicate under "Status" which elements are partially complete.

\begin{tabular}{|c|c|c|c|}
\hline $\begin{array}{c}* \text { ICAO } \\
\text { Reference }\end{array}$ & $\begin{array}{c}\text { Training aspect to } \\
\text { be analyzed }\end{array}$ & Answer & Status of Implementation \\
\hline
\end{tabular}

\begin{tabular}{|c|c|c|c|}
\hline \multicolumn{4}{|c|}{$\begin{array}{l}\text { B0- APTA: Optimization of approach procedures including vertical guidance } \\
\text { Requirements: revised approach procedures, aircraft equipment, ground equipment }\end{array}$} \\
\hline \multirow[t]{3}{*}{$\begin{array}{l}\text { Section } 3.1 \\
3.2 \\
5.2 .1\end{array}$} & $\begin{array}{l}\text { Has initial training } \\
\text { in procedures been } \\
\text { established? }\end{array}$ & $\begin{array}{ll}\text { O } & \text { Yes } \\
\circ & \text { No }\end{array}$ & \\
\hline & $\begin{array}{l}\text { Has training been } \\
\text { implemented for all } \\
\text { necessary } \\
\text { personnel? }\end{array}$ & $\begin{array}{ll}\text { O } & \text { Yes } \\
\text { O } & \text { No }\end{array}$ & \\
\hline & $\begin{array}{l}\text { Have new roles and } \\
\text { responsibilities } \\
\text { been identified and } \\
\text { communicated to } \\
\text { all necessary } \\
\text { personnel? }\end{array}$ & $\begin{array}{ll}\text { O } & \text { Yes } \\
\text { O } & \text { No }\end{array}$ & \\
\hline $\begin{array}{l}\text { Section } \\
4.1 .1\end{array}$ & $\begin{array}{l}\text { Have changes } \\
\text { linked to the } \\
\text { management of } \\
\text { increased } \\
\text { automation been } \\
\text { identified and } \\
\text { communicated to } \\
\text { all necessary } \\
\text { personnel? }\end{array}$ & $\begin{array}{ll}\text { O } & \text { Yes } \\
\circ & \text { No }\end{array}$ & \\
\hline
\end{tabular}




\begin{tabular}{|c|c|c|c|}
\hline Section 5.1 & $\begin{array}{l}\text { Have the risks } \\
\text { associated with } \\
\text { human performance } \\
\text { been identified? }\end{array}$ & $\begin{array}{ll}\text { O } & \text { Yes } \\
\text { o } & \text { No }\end{array}$ & \\
\hline & $\begin{array}{l}\text { Have strategies to } \\
\text { mitigate those risks } \\
\text { been developed and } \\
\text { communicated to } \\
\text { all necessary } \\
\text { personnel? }\end{array}$ & $\begin{array}{ll}\circ & \text { Yes } \\
\text { O } & \text { No }\end{array}$ & \\
\hline \multicolumn{4}{|c|}{$\begin{array}{l}\text { B0- WAKE: Increased runway throughput through optimized wake turbulence } \\
\text { separation } \\
\text { Requirements: Refinement of wake turbulence separation standards and procedures, } \\
\text { ground equipment }\end{array}$} \\
\hline \multirow[t]{3}{*}{$\begin{array}{l}\text { Section } 3.0 \\
\text { Section } \\
5.2 .1 \\
\end{array}$} & $\begin{array}{l}\text { Has initial training } \\
\text { in procedures been } \\
\text { established? }\end{array}$ & $\begin{array}{ll}\text { O } & \text { Yes } \\
\text { O } & \text { No }\end{array}$ & \\
\hline & $\begin{array}{l}\text { Has training been } \\
\text { implemented for all } \\
\text { necessary } \\
\text { personnel? }\end{array}$ & $\begin{array}{ll}\text { O } & \text { Yes } \\
\circ & \text { No }\end{array}$ & \\
\hline & $\begin{array}{l}\text { Have new roles and } \\
\text { responsibilities } \\
\text { been identified and } \\
\text { communicated to } \\
\text { all necessary } \\
\text { personnel? }\end{array}$ & $\begin{array}{ll}\text { O } & \text { Yes } \\
\text { O } & \text { No }\end{array}$ & \\
\hline $\begin{array}{l}\text { Section } \\
5.2 .1\end{array}$ & $\begin{array}{l}\text { Have changes } \\
\text { linked to the } \\
\text { management of } \\
\text { increased } \\
\text { automation been } \\
\text { identified and } \\
\text { communicated to } \\
\text { all necessary } \\
\text { personnel? }\end{array}$ & $\begin{array}{ll}\text { O } & \text { Yes } \\
\text { O } & \text { No }\end{array}$ & \\
\hline Section 5.1 & $\begin{array}{l}\text { Have the risks } \\
\text { associated with }\end{array}$ & $\begin{array}{ll}\text { O } & \text { Yes } \\
\circ & \text { No } \\
\end{array}$ & \\
\hline
\end{tabular}




\begin{tabular}{|l|l|l|l|}
\hline & $\begin{array}{l}\text { human performance } \\
\text { been identified? }\end{array}$ & \\
\hline $\begin{array}{l}\text { Have strategies to } \\
\text { mitigate those risks } \\
\text { been developed and } \\
\text { communicated to }\end{array}$ & $\circ$ Yes & \\
all necessary & & \\
personnel? & & \\
\hline
\end{tabular}

